\title{
PROGRAM KEMITRAAN MASYARAKAT: \\ PELATIHAN MANAJEMEN EVENT UNTUK KELOMPOK SADAR WISATA DI DESA WISATA PELA KECAMATAN KOTA BANGUN KABUPATEN KUTAI KARTANEGARA
}

\author{
Sabalius Uhai ${ }^{1)}$, Rini Koen Iswandari $\left(^{2)}\right.$, Novita Indriani $\oplus^{3)}$, Puji Kharisma Arifin $\mathbb{i}^{4)}$, dan Aulia Fitri \\ Nurhidayati (iD) \\ ${ }^{1,2}$ Usaha Perjalanan Wisata, Politeknik Negeri Samarinda \\ ${ }^{3}$ Pariwisata, Politeknik Negeri Samarinda \\ ${ }^{4,5}$ Usaha Perjalanan Wisata, Politeknik Negeri Samarinda \\ 1,2,3,4,5 Jl. Ciptomangunkusumo Kampus Gunung Panjang, Kota Samarinda, 75131 \\ E-mail : sabaliusuhai@polnes.ac.id ${ }^{1)}$, rini02@polnes.ac.id ${ }^{2)}$, novita20@polnes.ac.id ${ }^{3)}$, pujikharisma56@ gmail.com ${ }^{4)}$, \\ auliafitrinurhayati@gmail.com ${ }^{5)}$
}

\begin{abstract}
ABSTRAK
Sebuah event di desa wisata menjadi daya tarik dalam upaya meningkatkan jumlah pengunjung, sebuah event yang dikemas dengan baik dapat menjadi daya tarik para wisatawan atau pengunjung yang datang ke sebuah objek dan daya tarik wisata. Desa Wisata Pela adalah sebuah desa wisata yang menyelenggarakan sebuah event Festival Danau Semayang, dengan diadakan event ini diharapkan dapat meningkatkan jumlah kunjungan serta memberikan dampak secara ekonomi untuk masyarakat Desa Wisata Pela. Dalam upaya mencapai target yang diinginkan Program Studi Usaha Perjalanan Wisata melalui Kegiatan Pengabdian kepada Masyarakat menyelenggarakan Pelatihan Manajemen Event untuk Kelompok Sadar Wisata Desa Wisata Pela. Adapun tujuan dari kegiatan pengabdian kepada masyarakat ini adalah membantu anggota Kelompok Sadar Wisata Desa Wisata Pela untuk memahami dan mengerti tentang manajemen event. Dalam kegiatan pengabdian kepada masyarakat ini menggunakan metode partisipatif yakni adanya keterlibatan dari peserta, pihak peserta dan pendamping saling memberikan tanggapan baik itu pertanyaan maupun jawaban. Kegiatan yang dilakukan dalam bentuk seminar dan diskusi kelompok ini diikuti oleh 15 orang anggota Kelompok Sadar Wisata (Pokdarwis) Desa Wisata Pela. Setelah mengikuti kegiatan pelatihan ini peserta mendapat pemahaman tentang manajemen event, siap terlibat dalam kegiatan Festival Danau Semayang di masa yang akan datang.
\end{abstract}

Kata Kunci: Kelompok Sadar Wisata, Manajemen Event, Event, Kepanitiaan Event, Desa Wisata

\section{PENDAHULUAN}

Event merupakan salah satu instrumen komunikasi yang banyak dimanfaatkan oleh perusahaan atau lembaga tertentu untuk memperkenalkan diri kepada khalayaknya (Suhendara, F. I., Wardhani, 2015). Dampak dari sebuah kegiatan event adalah adanya peningkatan terhadap ekonomi masyarakat serta adanya upaya dari penyelenggara kegiatan untuk menjadi tuan rumah yang baik (Marpaung, 2015), (Rahayu, 2018), (Saputra, 2016). Kegiatan event juga sarana pemberdayaan masyarakat dalam pengembangan desa wisata (Andriyani, A. A. I., 2017). Niat perilaku pengunjung memainkan peran penting dalam memprediksi keuntungan masa depan dalam festival(Hung-Che $\mathrm{Wu}, 2013$ ), Hung-Che $\mathrm{Wu} \&$ Tao Li, 2015). Ketika sebuah event diselenggarakan maka pihak penyelenggara harus memperhatikan kepuasan para pengguna jasanya (Putra, 2018).

Pelaksanaan kegiatan pelatihan manajemen event adalah adanya semangat dan cinta terhadap mitra dalam hal ini adalah kelompok sadar wisata Desa Wisata Pela yang mana melibatkan perguruan tinggi sebagai wadah untuk berbagi kepada masyarakat. Kegiatan ini sebagai wujud nyata dari perguruan tinggi yakni dosen dan mahasiswa memasukan kegiatan Festival Danau Semayang sebagai bahan kajian maupun dalam kegiatan pengabdian kepada masyarakat. Tujuan dan target yang ingin dicapai dari Program Studi Usaha Perjalanan Wisata adalah ikut terlibat dalam kegiatan pembinaan desa wisata.

Fokus PKM ini adalah ingin menyukseskan kegiatan Festival Danau Semayang, sekaligus memperkenalkan Desa Wisata Pela sebagai desa wisata yang layak untuk dikunjungi oleh para pengunjung, dengan adanya para pengunjung akan memberikan dampak secara ekonomi bagi masyarakat Desa Wisata Pela(Nala, I W. L., Noor, M. F., Keliwar, S., Uhai, S., Sukmana, 2021).

Desa Pela adalah sebuah desa yang berada di Kecamatan Kota Bangun Kabupaten Kutai Kartanegara, Kalimantan Timur. Desa Pela ini terkenal dengan sebutan Desa Wisata Pela, kehadiran Pesut di Desa Pela menjadi daya tarik tersendiri. Para wisatawan yang berkunjung ke Desa Pela berharap dapat melihat Pesut, namun demikian 
tidak semua orang beruntung dapat melihat Pesut. Kondisi ini akan bergantung pada keadaan air yang ada di muara sungai menuju Danau Semayang, jika air surut maka Pesut lebih suka tinggal di sungai mahakam.

Pembangunan sektor kepariwisataan semakin berkembang saat ini baik secara nasional maupun regional/wilayah dan daerah, indikator perkembangan tersebut dapat dilihat dari berkembangnya bisnis industri kepariwisataan saat ini, mulai dari usaha hotel, home stay, usaha restoran, rumah makan, usaha daya tarik wisata dan kawasan pariwisata, usaha transportasi dan perjalanan wisata, usaha kegiatan hiburan dan rekreasi, usaha MICE (Meeting, Incentive, Convention, Exhibition), membuat event, dan usaha pariwisata lainnya yang berkembang saat ini (Nala, I W. L., Noor, M. F., Keliwar, S., Uhai, S., Sukmana, 2021).

Desa Wisata Pela sejak tahun 2018 hingga tahun 2021 telah melaksanakan Festival Danau Semayang, setiap tahun diadakan kegiatan Festival Danau Semayang, pada awalnya adalah Desa Pela merayakan ulang tahun desa, supaya kegiatannya lebih meriah dan memiliki daya jual maka kegiatan ulang tahun Desa Pela diganti dengan istilah Festival Danau Semayang. Kegiatan Festival Danau Semayang sudah menjadi agenda tahunan dan sudah tercatat dalam agenda tahunan Dinas Pariwisata Kabupaten Kutai Kartanegara (Alimin, 2020). Desa Wisata Pela menjadi perhatian dari berbagai kalangan pecinta pariwisata, termasuk para akademisi untuk datang ke desa ini untuk berbagi pengalaman dan ilmu, misalnya dari Jurusan Pariwisata Politeknik Negeri Samarinda mengadakan Pelatihan Pengelolaan Pondok Wisata (Sudarmayasa, I W. Nala, I W. L. Keliwar, 2020). Ekowisata sungai di Desa Pela sangat mendukung dalam kegiatan Festival Danau Semayang (Nala, I W. L., Indriani, 2021). Kegiatan Festival Danau Semayang diselenggarakan oleh Desa Wisata Pela memiliki dampak yang positif bagi masyarakat Desa Pela yakni membantu secara ekonomi(Nala, I W. L., Noor, M. F., Keliwar, S., Uhai, S., Sukmana, 2021a). Pengembangan pariwisata di perdesaan dengan metode partisipasi masyarakat merupakan sebuah kondisi ideal yang dapat tercapai atas dasar semangat masyarakat sebagai modal dasar dan utama, didukung oleh tersedianya sumber daya alam dan budaya, pemerintahan yang baik, dan didukung oleh akademisi atau lembaga lain sebagai fasilitator (Sari, 2019). Sektor industri pariwisata dalam membangun desa, dijadikan sebagai alternatif sektor dalam meningkatkan kesejahteraan ekonomi masyarakat desa (Yuliawati, A. K. Gautama, B. P. Rofaida, R. Wulung, S. R.P. Aryanti, 2020).

Adapun tujuan diadakannya pelatihan manajemen event untuk Kelompok Sadar Wisata (Pokdarwis) Desa Wisata Pela adalah untuk membantu para anggota Kelompok Sadar Wisata Desa Wisata Pela dalam menyelenggarakan kegiatan Festival Danau Semayang, sehingga penyelenggaraan kegiatan festival di masa yang akan datang menjadi lebih baik, dapat memberikan dampak positif bagi masyarakat Desa Wisata Pela, dapat memberikan kesan yang baik bagi para pengunjung yang datang di Desa Wisata Pela, Kecamatan Kota Bangun Kabupaten Kutai Kartanegara.

\section{RUANG LINGKUP}

Kajian ini dibatasi pada upaya untuk meningkatkan sumber daya manusia yakni dalam bidang manajemen event untuk para anggota Kelompok Sadar Wisata di Desa Wisata Pela Kecamatan Kota Bangun Kabupaten Kutai Kartanegara, Kalimantan Timur. Sebagaimana sudah dijelaskan sebelumnya bahwa untuk dapat meningkatkan sumber daya manusia dalam bidang event atau kegiatan festival di Desa Wisata Pela perlu diselenggarakan sebuah pelatihan manajemen event. Kegiatan ini dilakukan dalam ruang lingkup anggota Kelompok Sadar Wisata Desa Wisata Pela. Terbentuknya sebuah Kelompok Sadar Wisata (Pokdarwis) adalah dasar terbentuknya desa wisata. Kelompok Sadar Wisata inilah yang akan bertanggung jawab dalam pengelolaan di desa wisata. Desa Wisata Pela adalah sebuah Desa yang sudah menghasilkan dana lewat kegiatan kepariwisataan, potensi wisata yang dimiliki oleh Desa Wisata Pela adalah wisata alam, kebudayaan dan industri pengolahan ikan asin, memiliki museum nelayan. Ikan Pesut sungai mahakam menjadi objek wisata dan daya tarik wisata yang menjadi primadona di Desa Wisata Pela.

\section{BAHAN DAN METODE}

Kegiatan Pengabdian kepada Masyarakat ini diselenggarakan di Desa Wisata Pela Kecamatan Kota Bangun Kabupaten Kutai Kartanegara, yang menjadi peserta kegiatan ini adalah para anggota Kelompok Sadar Wisata (Pokdarwis) Desa Wisata Pela. Penyelenggara kegiatan pengabdian kepada masyarakat adalah Program Studi Usaha Perjalanan Wisata. Materi yang disampaikan dalam kegiatan pengabdian kepada masyarakat ini akan membahas tentang manajemen event, cara mengelola event, pembentukan kepanitiaan event, manajemen risiko. Dalam penulisan ini disajikan bahan kajian teoretis dan metode pengabdian kepada masyarakat. Apapun metode yang digunakan adalah partisipatif peserta kegiatan.

Manajemen event adalah organisasi dari suatu kegiatan yang diselenggarakan oleh komunitas atau lembaga yang dikelola secara profesional, efisien dan efektif dari perencanaan, pelaksanaan hingga penyelesaian kegiatan (Noor, 2017). Event merupakan kegiatan yang diselenggarakan untuk memperingati halhal penting baik secara individu maupun kelompok, kegiatan diselenggarakan untuk tujuan tertentu serta melibatkan lingkungan masyarakat. Salah satu tujuan sebuah event diselenggarakan adalah terdapat pada sasaran dan target pengunjung (Noor, 2017), (Adhitama, T. P., Asnur, 2019), (Marwan, I., Rahmat, A. A., Rohyana, 2018), (Hasybullah, 2019).

Event adalah kegiatan yang dilakukan setiap hari, bulan atau setiap tahun dengan membawa orang ke tempat untuk menerima informasi atau pengalaman penting dan tujuan lain yang di organisir oleh penyelenggara (Uhai, 
S., 2021). Menurut Noor event adalah peristiwa yang memperingati hal-hal penting dalam seluruh kehidupan manusia, baik secara individu maupun dalam kelompok yang berkaitan dengan adat, budaya, tradisi dan agama, yang diadakan untuk tujuan tertentu dan yang melibatkan lingkungan masyarakat pada waktu tertentu (Noor, 2017). Event adalah sebuah kegiatan yang diselenggarakan oleh seseorang, sekelompok orang untuk merayakan peristiwa dalam kehidupan ini. Event yang pernah diselenggarakan oleh Desa Wisata Pela, yakni Festival Danau Semayang. Festival ini pertama kali dirayakan pada tahun 2018 (Noor, S., 2021).

Manajemen event sukses akan ditentukan pada proses pertama riset, kedua desain, ketiga perencanaan, keempat koordinasi, kelima evaluasi(Noor, 2017), (Uhai, S., 2021), (Uljanatunnisa, H., Lusia, 2020).

Menurut Purwadarminta, Festival, dari bahasa Latin berasal dari kata dasar "festa" atau pesta dalam bahasa Indonesia. Festival biasanya berarti "pesta besar" atau sebuah acara meriah yang diadakan dalam rangka memperingati sesuatu. Atau juga bisa diartikan dengan hari atau pekan gembira dalam rangka peringatan peristiwa penting atau bersejarah, atau pesta rakyat (Uhai, S., 2021). Di Kalimantan Timur memiliki danau yakni Danau Jempang, Danau Melintang, Danau Semayang. Festival yang paling lama diselenggarakan pada awal tahun 1990-an adalah Festival Danau Jempang di Kecamatan Jempang Kabupaten Kutai Barat, pada tahun 1990-an masih bergabung pada Kabupaten Kutai (saat ini menjadi kabupaten induk yakni Kabupaten Kutai Kartanegara). Festival Danau Jempang memiliki khas pada pertunjukan kebudayaan yakni tarian massal, narasi tentang asal-usul Danau Jempang akan selalu dimunculkan saat diadakan kegiatan tersebut (Habibie, H., Uhai, 2021). yaitu Leisure Event, Cultural Event, Personal Event, dan organizational Event. Adapun penjelasannya adalah sebagai berikut:

1. Leisure Event. Merupakan kategori event yang banyak berkembang dalam kegiatan olahraga, di mana ada elemen kompetisi dan menarik banyak pengunjung.

2. Personal Event. Kegiatan yang di dalamnya melibatkan anggota keluarga atau teman di mana kategori acara dapat digambarkan sebagai lebih sederhana. Contoh acara pribadi termasuk mengatur pernikahan, dll.

3. Cultural Event. Merupakan kegiatan yang identik dengan budaya atau memiliki nilai sosial yang tinggi dalam jalinan masyarakat.

Dengan perkembangan pesat dan kemajuan teknologi, organisasi acara budaya akan lebih menarik dan mampu beradaptasi dengan situasi dan kondisi zaman modern, menghasilkan campuran yang mengesankan

Organizational Event. Bentuk event yang diselenggarakan pada tujuan organisasi. Contoh acara di acara organisasi adalah konferensi di sebuah partai politik, pameran yang diselenggarakan oleh suatu organisasi/perusahaan dengan kepentingan perusahaan. Menurut Noor (Noor, 2017) sebuah event yang menarik harus memiliki karakteristik dalam penyelenggaraannya, yaitu mempunyai ciri tersendiri dan cenderung memiliki perbedaan antara satu dengan lainnya. Adapun karakteristik event yang bagus yaitu sebagai berikut:

1. Uniqueness's

Kunci utama suksesnya sebuah event adalah pengembangan ide sehingga event memiliki keunikan tersendiri. Acara dengan warna berbeda tidak akan mudah dilupakan oleh kelompok sasaran. Keunikan dapat datang dari peserta yang berpartisipasi, lingkungan, para pengunjung ke acara tersebut dan banyak hal lain yang menjadikan acara tersebut unik dan berbeda dari yang lain.

2. Perishability

Yang dimaksud dengan perishability adalah kemungkinan terjadinya event yang tidak sesuai dengan rencana atau acara tidak hidup sehingga kurang memuaskan. Jika acara tidak diatur dengan baik tujuan yang ingin dicapai pada acara tersebut tidak akan tercapai.

3. Intangibility

Setelah menghadiri event, yang tertinggal di benak pengunjung adalah pengalaman yang mereka dapatkan dari penyelenggaraan event. Merupakan tantangan bagi penyelenggara untuk mengubah bentuk layanan tidak berwujud menjadi sesuatu yang nyata sehingga bentuk sekecil apa pun yang digunakan pada acara tersebut dapat mengubah persepsi pengunjung. Seperti penggunaan kualitas audio-video yang selalu diingat pengunjung acara.

4. Personal Interaction

Personal interaction merupakan salah satu karakteristik yang penting pada saat event berlangsung. Pengunjung yang datang ke suatu acara juga memainkan peran utama dalam kesuksesan acara tersebut. Misalnya, partisipasi aktif penonton dalam acara konser musik di mana penonton berpartisipasi dalam menyanyi untuk berkontribusi pada kinerja acara (Uhai, S., 2021).

Menurut Noor Manajemen event adalah organisasi dari suatu kegiatan yang diselenggarakan oleh komunitas atau lembaga yang dikelola secara profesional, efisien dan efektif dari perencanaan, pelaksanaan hingga penyelesaian kegiatan(Noor, 2017)

Acara yang sukses terdiri dari lima fase penting yang harus dipertimbangkan yaitu: research, design, Planning, coordination, dan evaluation. Adapun penjelasan tahapan pelaksanaan event adalah sebagai berikut:

1. Research

Dalam melaksanakan sebuah event terdapat lima pertanyaan (why, who, when, where, what) untuk memutuskan bagaimana mengadakan suatu acara: mengapa suatu acara harus diadakan? Siapa penonton acara tersebut? Kapan acara akan berlangsung? Dimana acara berlangsung? dan apa yang akan ditampilkan di acara tersebut? 
Setelah menjawab lima pertanyaan, analisis SWOT (strength, weakness, opportunity, threats) akan dilakukan untuk memastikan bahwa semua fase dijalankan secara sistematis.

2. Design

Ide baru dapat membantu membuat aktivitas yang sesuai dengan tujuan dari pelaksanaan event yang dapat dilakukan dengan cara brainstorming (curah pendapat) dan mind mapping (pemetaan pikiran). Kreativitas harus sangat didukung oleh pengelola acara karena pada akhirnya produk yang ditawarkan adalah seni kreatif. Kreativitas adalah alfa dan omega dalam setiap proses manajemen acara. Brainstorming dan Mind Mapping adalah kegiatan di mana semua anggota dikumpulkan dan ide-ide mereka disampaikan dan kemudian dihubungkan dan disatukan ke dalam filosofi acara yang memperhitungkan aspek keuangan, sosial, budaya dan aspek penting lainnya dari menjalankan suatu acara. Brainstorming berfokus pada tema dan konsep acara yang di dekorasi dan dirancang secara artistik, hiburan yang disajikan, strategi komunikasi yang digunakan, dan sebagainya. Dalam fase ini, studi kelayakan untuk acara-acara juga akan dilakukan untuk menyaring ideide kreatif yang muncul. Studi kelayakan ini akan memperhatikan anggaran, sumber daya manusia dan kondisi politik.

3. Planning

Tahap perencanaan adalah tahap paling lama dalam proses manajemen event. Ketika fase penelitian dan desain selesai dengan baik, fase perencanaan dapat dengan mudah diselesaikan. Namun, jika penelitian dan desain tidak dilakukan dengan baik, sangat mungkin bahwa akan ada ketidak sesuaian dalam fase perencanaan dan perubahan pada rencana utama akan dilakukan dengan rencana penggantian. Tahap perencanaan didasarkan pada tiga dasar hukum: waktu, lokasi, dan kecepatan. Pandangan ke depan dalam menggunakan ketiga hal ini akan sangat mempengaruhi hasil dari acara yang sedang diadakan.

4. Coordination

Koordinasi merupakan tahap yang paling banyak dilakukan saat pelaksanaan atau eksekusi pada tahap sebelumnya yakni mengeksekusi rencana yang telah dibentuk dengan matang. Pada tahap ini, peran manajer acara sangat penting ketika manajer acara dihadapkan dengan banyak keputusan yang membutuhkan pengambilan keputusan profesional untuk memiliki dampak yang baik pada hasil acara.

5. Evaluation

Evaluasi merupakan tahap dimana dilakukan penilaian pada event dari tahap pertama hingga event telah selesai diselenggarakan. Evaluasi peringkat itu sendiri berfungsi sebagai referensi untuk mengatur acara serupa yang akan terjadi selanjutnya. Dalam melaksanakan kegiatan event pembentukan kepanitiaan adalah sebuah hal yang perlu diperhatikan. Kepanitiaan adalah sekelompok orang yang ditunjuk atau dipilih untuk mempertimbangkan atau mengurus hal-hal yang ditugaskan kepadanya (Uhai, S., 2021).

Kegiatan Pengabdian kepada Masyarakat ini adalah kegiatan dari Pusat Penelitian dan Pengabdian kepada Masyarakat Politeknik Negeri Samarinda dan program ini merupakan kuota Program Studi Usaha Perjalanan Wisata. Ketika mendapat informasi bahwa Program Studi Usaha Perjalanan Wisata, langkah selanjutnya membuat proposal yang ditujukan kepada P3M Politeknik Negeri Samarinda.

Tahap selanjutnya adalah menghubungi ketua Kelompok Sadar Wisata Desa wisata Pela, untuk menginformasikan bahwa akan ada kegiatan pengabdian kepada masyarakat, dimana kegiatan tersebut akan diadakan di Desa Wisata Pela, pada hari jumat tanggal 27 Agustus 2021 sampai hari Sabtu tanggal 28 Agustus 2021. Pelaksanaan kegiatan Pengabdian Kepada Masyarakat ini menggunakan metode partisipatif yakni adanya kerja sama antara narasumber dengan peserta.

\section{PEMBAHASAN}

Pengabdian Kepada Masyarakat ini dilaksanakan melalui dua tahap, yakni bagian pertama adalah pemaparan materi tentang manajemen event, kepanitiaan, merencanakan kegiatan event, manajemen risiko dalam sebuah kegiatan event, sedangkan tahap kedua adalah melaksanakan diskusi bersama para peserta dari Kelompok Sadar Wisata Desa Wisata pela.

\subsection{Pertemuan Hari Pertama}

Pertemuan hari pertama diadakan pada tanggal 27 Agustus 2021, pada pukul 14.00 WITA di Kantor Kepala Desa Pela. Kegiatan pengabdian kepada masyarakat diawali dengan acara pembukaan, supaya acara teratur dipandu oleh seorang MC (Master of Ceremony), acara dibuka oleh MC yang dibawakan oleh Puji Kharisma Arifin, menyanyikan lagu Indonesia Raya, acara sambutan-sambutan. Sambutan pertama adalah Pak Sabalius Uhai, SST. Par., M. Par. Sebagai Ketua Panitia Pengabdian Kepada Masyarakat dari Program Studi Usaha Perjalanan Wisata, sambutan kedua oleh ketua Kelompok Sadar Wisata (Pokdariwis) Desa Wisata Pela yakni Pak Alimin. Sambutan ketiga oleh Bapak Kepala Desa yakni Pak Sopyan Noor, sekaligus membuka kegiatan pelatihan manajemen event untuk Kelompok Sadar wisata Desa Wisata Pela. Setelah acara pembukaan dilanjutkan pemberian materi tentang manajemen event.

Materi pelatihan manajemen event adalah sebuah pelatihan yang membahas tentang event, merencanakan event, pembentukan kepanitiaan, manajemen risiko. Kegiatan pembukaan pelatihan manajemen event dapat dilihat pada gambar 1 . 


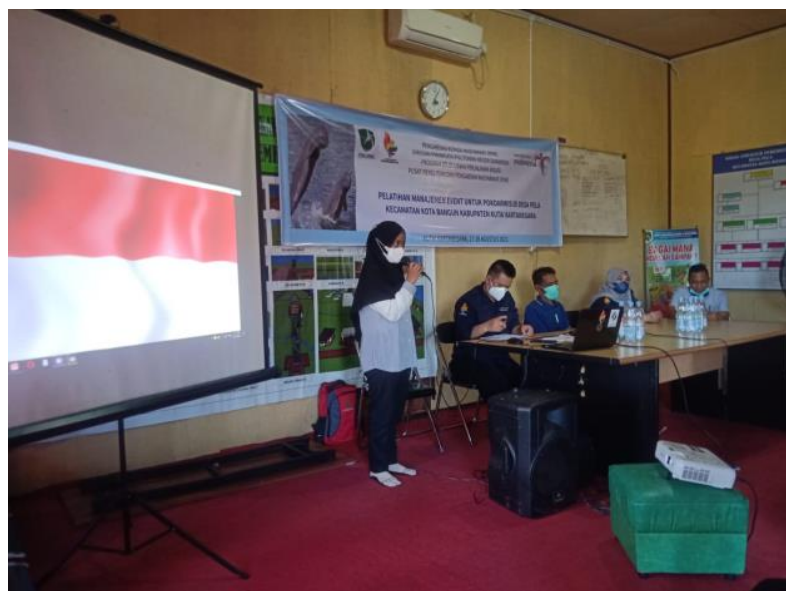

Gambar 1. Acara kegiatan pembukaan PKM

Setelah acara pembukaan dilanjutkan dengan penyampaian materi tentang manajemen event. Materi manajemen event yang dibahas adalah pengertian event, jenis-jenis event, kegiatan event yang biasanya sering diselenggarakan di desa. Kegiatan penyampaian materi dapat dilihat pada gambar 2 .

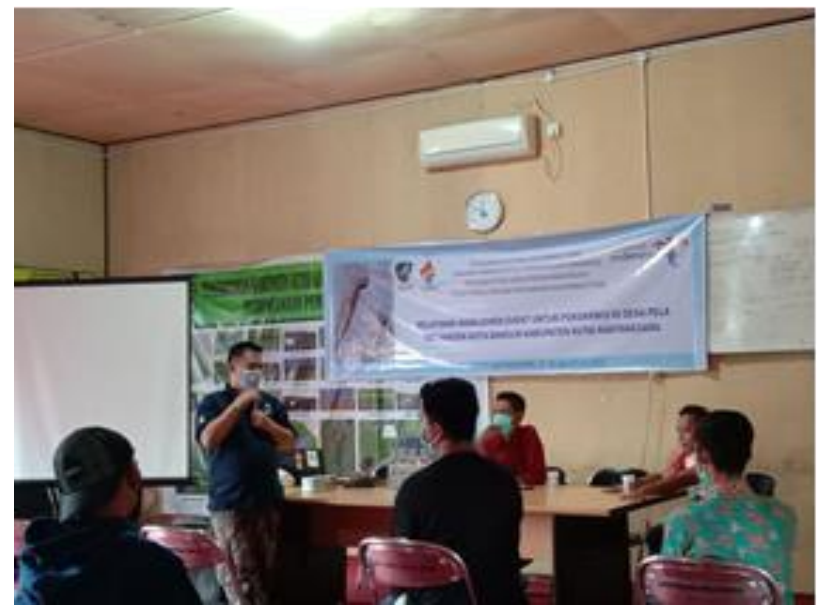

Gambar 2. Saat presentasi materi event

Dapat dilihat pada gambar 2. Kegiatan presentasi dan diskusi bersama peserta yang ikut pelatihan manajemen event. Dalam diskusi bersama ada beberapa hal yang perlu dibahas adalah:

1. Apa yang peserta Kelompok Sadar Wisata 3B Desa Wisata Pela ketahui tentang event ?

2. Event apa saja yang telah dilaksanakan di Desa Wisata Pela?

3. Apakah para panitia event Festival Danau Semayang mengerti dan memahami tentang tugas dan tanggung jawabnya masing-masing ?

4. Hambatan dan kendala yang dihadapi saat melaksanakan kegiatan Festival Danau Semayang ?

5. Apakah panitia Festival Danau Semayang tahu bahwa setiap kegiatan event akan ada risiko yang muncul?
6. Apakah panitia Festival Danau Semayang mengadakan evaluasi kegiatan setelah kegiatan diselenggarakan.

Para peserta menjawab pertanyaan tersebut dengan baik, secara umum para peserta dapat memahami dengan baik apa yang menjadi tugas dan tanggung jawabnya, meskipun ada kendala yakni tidak memiliki pengalaman kegiatan sebelumnya, para peserta merasa minder atau malu ketika berhadapan dengan pengunjung yang datang dari kota, kurangnya koordinasi antar panitia sehingga munculnya tidak kesesuaian kegiatan ketika ada perubahan jadwal kegiatan event yang telah dibuat bersama.

Kegiatan Festival Danau Semayang yang diselenggarakan mengambil tema kehidupan para nelayan yakni kegiatan mengadakan lomba menjala, lomba menangkap ikan secara langsung dengan menggunakan tangan secara langsung, lomba ketinting, lomba perahu. Kegiatan festival yang dilaksanakan di sungai Pela dan danau Semayang Kegiatan Festival Danau Semayang dapat dilihat pada gambar 3 .

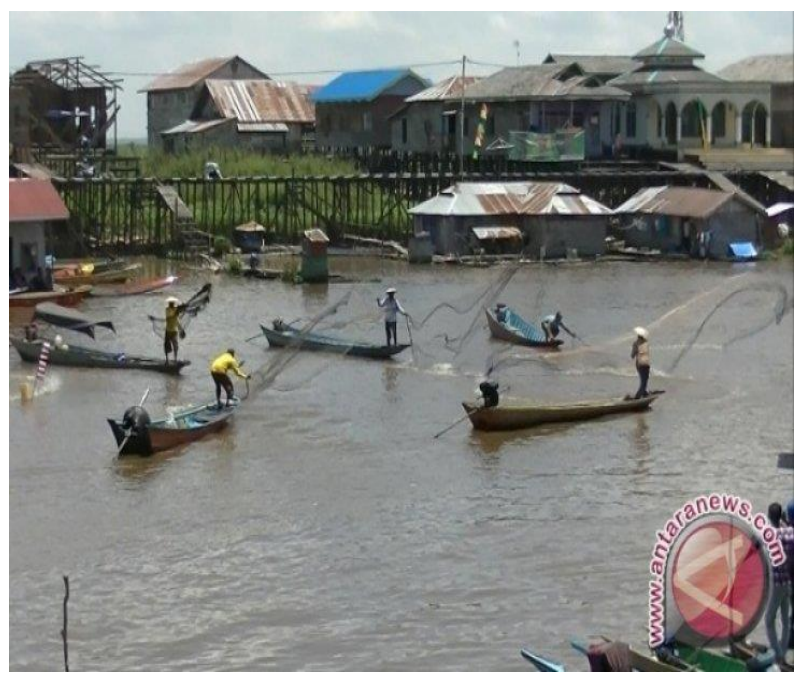

Gambar 3. Festival Danau Semayang

\subsection{Pertemuan Hari Kedua}

Pada hari kedua, digunakan untuk berbagi pengalaman ketika para peserta terlibat dalam kepanitiaan Festival Danau Semayang. Adapun yang ditemui saat berbagi pengalaman.

1. Kendala yang dihadapi

Kendala yang dihadapi oleh anggota Kelompok Sadar Wisata (Pokdarwis) adalah para peserta tidak diberikan pengetahuan yang baik tentang tugas dan tanggung jawabnya masing-masing, saling menunggu perintah dari ketua panitia, saat evaluasi kegiatan tidak dicatat dan dilaksanakan dengan baik, sebagian anggota panitia Festival Danau Semayang merasa minder dan merasa malu ketika bertemu orang baru atau orang dari perkotaan. Rasa minder muncul karena faktor bahasa yang masih terbiasa menggunakan 
bahasa lokal, terkadang berpikir mereka tidak diterima dengan baik dari orang-orang baru. Para anggota pelatihan meminta bahwa diberikan kesempatan untuk menjadi ketua panitia yang mana selama ini yang menjadi ketua adalah ketua Pokdarwis yakni Pak Alimin. Para peserta yang meminta untuk diberikan kesempatan bagi anggota baru supaya mereka diberikan kesempatan untuk belajar dan berlatih menjadi bagian dari kepanitiaan.

2. Acara Penutupan Kegiatan Pelatihan

Kegiatan selanjutnya adalah penutup, acara penutup ditutup oleh Bapak Kepala Desa Pela yakni Pak Sopyan Noor, Pak Sopyan Noor sangat berterima atas kegiatan pelatihan manajemen event sangat membantu para anggotaa Pokdarwis untuk mempersiapkan Festival Danau Semayang yang lebih baik di masa yang akan datang. Kegiatan penutup pelatihan manajemen event dapat dilihat pada gambar 4.

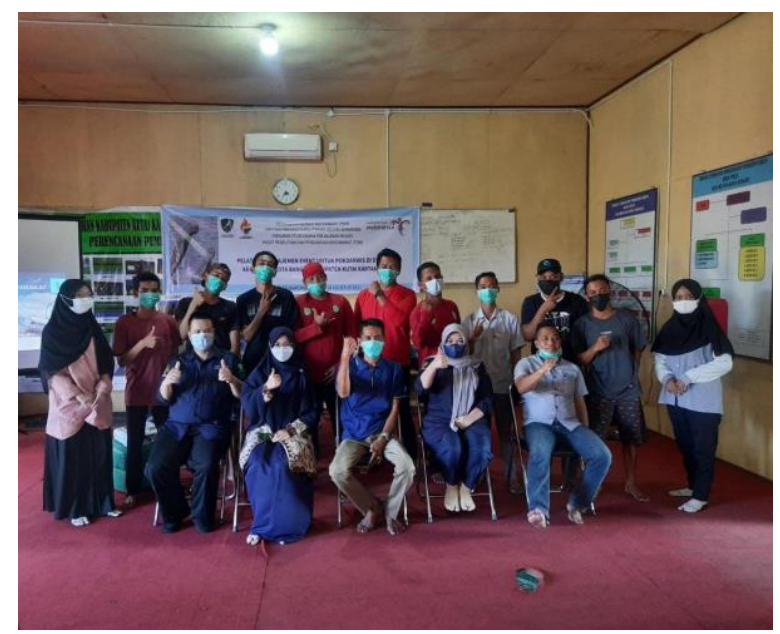

Gambar 4. Acara penutupan pelatihan

\section{KESIMPULAN}

Pengabdian kepada masyarakat ini adalah sebuah pelatihan manajemen event yakni sebuah proses membuat rencana kegiatan event, dalam pelatihan ini peserta akan mempelajari tentang manajemen event, merencanakan event, membentuk kepanitiaan kegiatan event, menentukan tugas dan tanggung jawab dari masingmasing panitia serta belajar manajemen risiko dalam sebuah kegiatan event. Para peserta juga berbagi pengalaman mereka saat menjadi bagian panitia Festival Danau Semayang.

\section{SARAN}

Kegiatan pengabdian kepada masyarakat ini adalah pelatihan manajemen event untuk Kelompok Sadar Wisata (Pokdarwis) di Desa Wisata Pela Kecamatan Kota Bangun Kabupaten Kutai Kartanegara, manfaat yang diharapkan dari kegiatan ini adalah dapat membantu para peserta untuk menjadi pribadi yang mampu melaksanakan tugas dan tanggung jawab sebagai seorang panitia pelaksana di lapangan. Disarankan peserta dapat mempraktikkan ilmu yang telah diperoleh saat mengikuti pelatihan manajemen event. Kegiatan pengabdian kepada masyarakat selanjutnya adalah pelatihan membuat personal event.

\section{DAFTAR PUSTAKA}

Adhitama, T. P., Asnur, L. (2019). Analisis Manajemen Event di KYRIAD HOTEL Bumiminang Padang. Jurnal Ilmu Sosial Dan Humaniora (JISH), Vol.8, No.(Ilmu Sosial dan Humaniora), 213-220. https://doi.org/http://dx.doi.org/10.23887/jishundiksha.v8i2.21458

Alimin. (2020). Laporan Kegiatan POKDARWIS BEKAYUH BAUMBAI BEBUDAYA (3B) Desa Wisata Pela Kecamatan Kota Bangun.

Andriyani, A. A. I., M. E. M. (2017). Pemberdayaan Masyarakat Melalui Pengembangan Desa Wisata Dan Implikasinya Terhadap Ketahanan Sosial Budaya Wilayah (Studi Di Desa Wisata Penglipuran Bali). Jurnal Ketahanan Nasional, Volume 23, 1-16. https://core.ac.uk/download/pdf/205956099.pdf

Habibie, H., Uhai, S. (2021). Sejarah Kampung Tanjung Jan (H. Uhai, Sabalius, Habibie (ed.)). Literasi Nusantara. www.penerbitlitnus.co.id

Hasybullah, M. A. (2019). Manajemen Special Event Upacara Adat "Seren Taun" Cigugur Kuningan. Jurnal Ilmu Komunikasi, Vol. 3, No(Ilmu Komunikasi), 53-68. https://doi.org/https://doi.org/10.15575/cjik.v3i1.5 203

Hung-Che Wu \& Tao Li. (2015). An Empirical Study of the Effects of Service Quality, Visitor Satisfaction, and Emotions on Behavioral Intentions of Visitors to the Museums of Macau. Journal of Quality Assurance in Hospitality \& Tourism, 16:1, 80102.

https://doi.org/https://doi.org/10.1080/1528008X.2 015.966298

Hung-Che Wu, J. W.-C. W. \& C.-C. C. (2013). An Empirical Study of Behavioral Intentions in the Food Festival: The Case of Macau. Asia Pacific Journal of Tourism Research, 19:11, 1278-1305. https://doi.org/https://doi.org/10.1080/10941665.2 013.844182

Marpaung, Y. K. (2015). Dampak Penyelenggaraan Event Piala Eropa 2012 (UEPA EURO) Terhadap Ekonomi dan Politik Ukraina. Jurnal Online Mahasiswa, Volume 2 N(Ilmu Hubungan Internasional), $1-11$. https://jom.unri.ac.id/index.php/JOMFSIP/article/v iew/7338

Marwan, I., Rahmat, A. A., Rohyana, A. (2018). Pelatihan Pengelolaan Manajemen Event Pertandingan Olahraga untuk Pengurus dan Anggota KONI Kota Tasikmalaya. Jurnal Pengabdian Siliwangi, Vol. 4, 
No(berbagai macam bidang keilmuan.), 179-185. http://jurnal.unsil.ac.id/index.php/jps/article/view/6 74

Nala, I W. L., Indriani, N. (2021). Pengembangan Ekowisata Sungai Berbasis Masyarakat di Desa Pela Kutai Kartanegara, Kalimantan Timur. Journal of Tourism and Creativity, Vol. 4, No(Tourism Destination And Catastrophe), 85-94. https://doi.org/https://doi.org/10.19184/jtc.v4i2.14 579

Nala, I W. L., Noor, M. F., Keliwar, S., Uhai, S., Sukmana, E. (2021a). Analisis Dampak Event Festival Danau Semayang terhadap Sosial dan Ekonomi. Literasi Nusantara. www.penerbitlitnus.co.id

Nala, I W. L., Noor, M. F., Keliwar, S., Uhai, S., Sukmana, E. (2021b). Pemetaan Pasar Pariwisata Kabupaten Kutai Kartanegara. Literasi Nusantara. www.penerbitlinus.co.id

Noor, S., A. (2021). Sejarah Festival Danau Semayang. Manuskrip Wawancara.

Noor, A. (2017). Manajemen Event (edisi revisi). Alfabeta. http://cvalfabeta.com/product/manajemen-event/

Putra, A. D. (2018). Analisa Kepuasan Pelanggan Event Organizer XYZ Menggunakan Metode Service Quality. Jurnal Ilmiah Teknologi Informasi, Volume 13, 41-45. https://doi.org/https://doi.org/10.35842/jtir.v13i2.2 31

Rahayu, I. (2018). Dampak Penyelenggaraan Event Pariwisata Dragon Boat Race di Kota Tanjungpinang. Jurnal Master Pariwisata (JUMPA), Volume 5, 211-226. https://doi.org/https://doi.org/10.24843/JUMPA.20 18.v05.i01.p11

Saputra, H. (2016). Dampak Pelaksanaan Event Internasional Sail Indonesia terdampak Perkembangan Wisata Bahari Bahari Indonesia. Jurnal Online Mahasiswa, Volume 3,(1-17). https://media.neliti.com/media/publications/12511 2-ID-none.pdf
Sari, Y. K. (2019). Pendampingan Berkelanjutan terhadap Pengembangan Pariwisata Desa Selopamioro. Bakti Budaya (Jurnal Pengabdian Kepada Masyarakat), Volume 2, 58-66. https://doi.org/https://doi.org/10.22146/bb.45040

Sudarmayasa, I W. Nala, I W. L. Keliwar, S. (2020). Pelatihan Pengelolaan Pondok Wisata bagi Kelompok Sadar Wisata Desa Pela, Kecamatan Kota Bangun, Kabupaten Kutai Kartanegara. Jurnal Sebatik, Vol. 24, N(Multidisciplinary), 51. https://jurnal.wicida.ac.id/index.php/sebatik/article /view/903/262

Suhendara, F. I., Wardhani, I. J. T. (2015). Manajemen Event Pameran Pernikahan Tradisional Lintaswarna. Prosiding Manajemen Komunikasi, 139-144. http://karyailmiah.unisba.ac.id/index.php/mankom/ article/viewFile/2159/pdf

Uhai, S., S. F. (2021). Manajemen Event di Desa Wisata. Literasi Nusantara. www.penerbitlitnus.co.id

Uljanatunnisa, H., Lusia, A. V. (2020). Analisis Manajemen Event (Studi Kasus Program CSR Wirausaha Muda Mandiri 2019). Jurnal Ilmu Komunikasi, Vol. 3, No(Ilmu Komunikasi), 95109.

https://doi.org/http://dx.doi.org/10.33021/exp.v3i1. 1068

Yuliawati, A. K. Gautama, B. P. Rofaida, R. Wulung, S. R.P. Aryanti, A. N. (2020). Peningkatan Kapasitas Komunitas Pariwisata Desa Tentang Parwisata Kreatif di Belitung Timur. Jurnal Pengabdian Masyarakat Multidisiplin, Volume 3, 110-117. https://doi.org/https://doi.org/10.36341/jpm.v3i2.1 149

\section{UCAPAN TERIMA KASIH}

Ucapan terima kasih kepada P3M Politeknik Negeri Samarinda, Jurusan Pariwisata, Program Studi D4 UPW dan D3 Pariwisata, Pemerintah Desa Wisata Pela, Kelompok Sadar Wisata Desa Wisata Pela. 